\title{
Relating extension education to the adoption of sustainable forest management practices
}

\author{
by Maminiaina S. Rasamoelina1, James E. Johnson2,"* and R. Bruce Hull ${ }^{3}$
}

\begin{abstract}
Family forest lands represent a vitally important economic, environmental, and social resource in the U.S. A study of family forest owners was conducted in Virginia in 2007 to determine the relationship between attendance at Extension Service educational programs and the adoption of sustainable forest management practices. A mail survey was conducted to 3435 randomly selected forest owners, with a usable response rate of $32 \%$. Participation in educational programs was shown to be significantly related to higher levels of adoption for all seven categories of sustainable forest management practices studied. For example, in the woodland management category, participants in workshops offered through the Virginia Forest Landowner Education Program (VFLEP) adopted one or more specific practices at a rate of 94\%, significantly greater than $83 \%$ for forest owners who attended other general educational programs, which in turn was significantly higher than the $75 \%$ adoption rate for forest owners who did not attend any educational programs. Two key indicators of sustainable forest management are the preparation and use of a forest management plan, and the use of professional technical assistance providers. For both of these categories participants in the VFLEP adopted at significantly higher rates, $41 \%$ and $73 \%$, respectively.
\end{abstract}

Keywords: sustainable forest management, extension, adoption, educational evaluation, private forest landowners

\section{RÉSUMÉ}

Les boisés familiaux constituent une ressource économique, environnementale et sociale d'une importance capitale aux É.-U. On a mené en 2007 une étude sur les propriétaires de boisés familiaux de Virginie afin de voir s'il y avait une relation entre les inscriptions aux programmes de formation des services forestiers et ladhésion à la foresterie durable. Ce sondage sest fait au moyen d'un sondage postal auprès de 3435 propriétaires de boisés privés choisis au hasard qui a donné $32 \%$ de réponses utilisables. Le sondage révèle une relation significative entre la participation aux programmes de formation et une forte adhésion aux sept catégories de techniques d’aménagement forestier durable étudiées. À titre d’exemple, dans la catégorie de l'aménagement des boisés, les participants aux ateliers offerts par le Virginia Forest Landowner Education Program (VFLEP) ont adopté une ou plusieurs des techniques spécifiques dans une proportion de $94 \%$; cest un pourcentage significativement plus élevé que les $83 \%$ pour les propriétaires de boisés privés qui ont participé aux autres programmes généraux de formation; ce pourcentage était lui-même significativement plus élevé que celui de $75 \%$ pour les propriétaires de boisés privés qui navaient participé à aucun programme de formation. Cette étude a retenu deux principaux indices de l'aménagement forestier durable soit lélaboration et l'utilisation d'un plan d'aménagement forestier et le recours à des services techniques professionnels. Les participants aux ateliers du VFLEP les ont adoptées dans des proportions significativement plus élevées de $41 \%$ et de $73 \%$ respectivement.

Mots clés : aménagement forestier durable, service de formation, adoption, évaluation de la formation, propriétaires de boisés privés

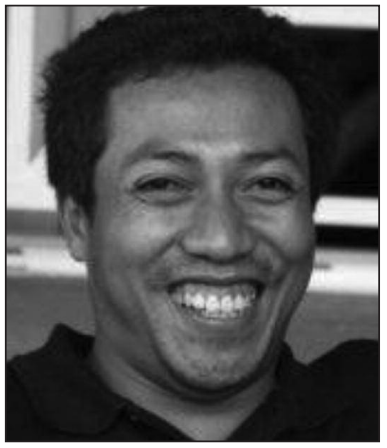

Maminiaina S. Rasamoelina

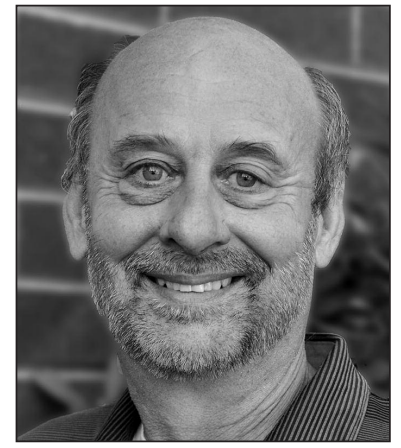

James E. Johnson

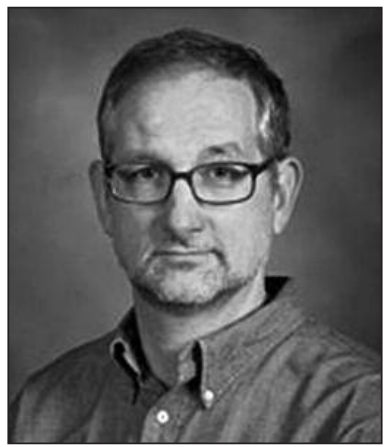

R. Bruce Hull

${ }^{1}$ WWF Madagascar and West Indian Ocean Programme Office, II-M-85 Ter, Antsakaviro, Antananarivo 101, Madagascar ${ }^{2}$ College of Forestry, 109 Richardson Hall, Oregon State University, Corvallis, Oregon 97333, *corresponding author: jim.johnson@ oregonstate.edu;

${ }^{3}$ Department of Forest Resources and Environmental Conservation, 310 Cheatham Hall, Virginia Tech, Blacksburg, Virginia 24061 


\section{Introduction}

The United States is rich in forest land, with a total of nearly 300 million ha scattered across all 50 states. Interestingly, 56\% of this forest land is privately owned, with $35 \%$ in the category of family forest land (Butler 2008). Nationally there are about 10.4 million family forest owners, who collectively own nearly 104 million ha. The average size of a family forest is about 10 ha (Butler 2008), though the majority of landowners own much less. These private forest lands are vitally important to society, as well as to the owners themselves. They provide a wide array of social, economic, and environmental benefits to society, including wood for a variety of products, habitat for fish and wildlife, clean water, recreation and scenic beauty, and open space. Therefore, society has a particular interest in the stewardship of these private lands, and in the U.S. both state and federal governments have long provided assistance for family forest owners in the form of educational programs, technical assistance, and financial incentive programs (USDA Forest Service 1998).

In Virginia, about 402000 family forest owners own collectively over 3.9 million ha (Butler 2008). A fairly high proportion (45\%) is owned by retirees, with $33 \%$ owned by working professionals, $11 \%$ by blue collar workers, and $11 \%$ by farmers (Birch et al. 1998). In Virginia, about 17\% have a written management plan (Birch et al. 1998), which is well above the national average of 3.6\% (Butler 2008). Virginia has had a long history of providing services to family forest owners. The Virginia Cooperative Extension Service has had a Forestry Extension Program in the state since 1925. The Virginia Department of Forestry has provided technical assistance for management, reforestation, and harvesting for many years, and more recently has assisted with recommending and monitoring the use of best management practices for water quality and enhancing site productivity.

In order to improve educational services to Virginias family forest owners, in 1996 the Virginia Forest Landowner Education Program (VFLEP) was created through a partnership with the Sustainable Forestry Initiative, the Virginia Forestry Association, the Virginia Department of Forestry, and Virginia Tech's College of Natural Resources and Cooperative Extension Service (Johnson et al. 2004). The objective of the VFLEP is to educate Virginia's family forest owners and encourage them to:

- Obtain professional technical assistance;

- Develop and implement a written management plan;

- Utilize financial assistance through multiple cost-share programs, if applicable; and,

- Adopt sustainable forest management practices.

VFLEP is a highly interactive program, with input and feedback provided by family forest owners through multiple, geographically-based Forest Landowner Councils scattered across the state (Johnson 2000). These Councils are empowered to deliver, using local professional foresters as instructors, a series of 12-hour workshops designed to achieve the objectives listed above. From October 1997 through February 2004, nearly 2000 family forest owners had attended one or more of the following three workshops: Woodland Options; Wildlife Options; and, Timber Harvesting and Marketing. In recent years, additional workshops such as Financial Assis- tance Options and Forest and Farmland Conservation Strategies have been added to the mix.

This study was established to evaluate the effectiveness of the three original VFLEP workshops in moving the forest owner participants toward adoption of sustainable forest management practices.

\section{Methods}

We had three main groups within the forest owner target population: owners who had attended at least one of the VFLEP shortcourses; owners who had not attended any of the three courses offered under the VFLEP program but attended at least one other educational program related to forest management; and, owners who attended neither the VFLEP courses nor any other educational program. The three groups had a common denominator in that all forest owners had been exposed to a common level of awareness concerning the possibility of attending educational programs through the Virginia Forest Landowner Update newsletter. This paper focuses on the hypothesis that there are no differences in adoption of sustainable forest management practices between the three groups of family forest owners.

The study population for this research included family forest owners who were listed in the VFLEP database. This large database had been compiled over many years, and consisted of forest owners who attended some type of educational programs offered through the Virginia Cooperative Extension Service, as well as forest owners selected at random from county tax rolls. All forest owners in the database who owned at least 0.8 ha of forest land in Virginia were included, resulting in a survey population of 5793 forest owners. A proportionate stratified random sampling design was used to select 3435 forest owners (60\% of the survey population), which kept the same proportions of individuals in the three groups in the final sample as in the original population. Thus, the final sample included 1038 owners in the VFLEP group and 2397 in the non-VFLEP group. The third group was developed following the survey.

For validity purposes, the survey questionnaire was pilot tested; it was mailed to 120 family forest owners using an advance letter that alerted them to the survey, followed by the survey package (cover letter, questionnaire, self-addressed stamped return envelope) a week later. For practical reasons, the pilot test was conducted with forest owners living in Montgomery County, Virginia. After all responses from the pilot test were gathered, a focus group consisting of local family forest owners was held to ensure the validity of the questions. Focus group participants made comments, and provided suggestions about unclear questions which had been identified in the pilot test. The focus group was also used to obtain input from respondents about the presentation of the survey (length, format, wording of questions, font size).

The questionnaire was mailed after analysis of the pilot test, and correction and revision following the focus group. It was administered using a slightly modified version of the tailored-design method (Dillman 2000) by using two waves of mailings of the survey packet (advance letter, cover letter, questionnaire, self-addressed stamped return envelope), and a wave of reminder cards to initial non-responders after a month. The first mailing was in late April 2007. A month after the first reminder card was sent, a second mailing was made 
of the survey packet together with a further reminder, for non-respondents. Recipients were requested to return the questionnaire even if they did not fill it out, and to provide a reason why it was not filled out.

The potential bias of non-response was evaluated by comparing late and early returners of the questionnaire. We assumed that non-respondents would be similar to late returners so we compared demographic characteristics (age, level of education, household income, land size, length of ownership) using an independent t-test to compare means (Groves et al. 2002). Six of the seven characteristics were not significant ( $p>0.94$ ): land size, length of ownership, age, level of education, total household income, and percentage of income gained from forest-related activities. Only the distance between the specific residency and the nearest forest tract owned was significant $(\mathrm{t}=2.127$; $\mathrm{p}$-value 0.034$)$, with early returners of the questionnaire living farther from their forest land than late returners. In light of these results, we considered non-response bias to be minimal and did not conduct further tests.

Through the survey, the respondents were queried as to their adoption of one or more practices following their attendance at educational programs or, in the case of those forest owners who did not attend any educational programs, adoption was independent of program attendance. Adoption was defined as use of one or more of the practices in a category.

The testing hypothesis was that there was no significant difference in adoption of various sustainable forest management practices among the three categories of forest owners. The hypothesis was tested using a one way Analysis of Variance (ANOVA). When the ANOVA results showed significant differences at the 0.10 level, we used a post-hoc test to identify which groups differed. The method used for the posthoc test depended on whether there was equality of variance across the three groups. The Levene test was used to test the equality of variance (if its result shows a significant difference, then unequal variance is assumed, but if not, equal variance is assumed). Depending on the outcome of the test of equality of variance, either the Tamhane's test (which is based on the t-test), or the Fisher's Least Significant Difference (LSD) method was used to determine which means differed. The first was used if variances were unequal and the second for equal variances. All tests used a level of significance of 0.10 . The requirements proposed by Lunney (1970) for the use of ANOVA with dichotomous variables were followed for each of the tests.

\section{Results and Discussion Demographics}

The survey respondents were placed into one of three categories: (a) those who had attended one or more of the VFLEP workshops; (b) those who did not attend a VFLEP workshop, but had some other experience with extension education, such as field tours; and, (c) those who had no experience with forestry-related educational programs of any type. We labeled these as (a) VFLEP, (b) Other, and (c) None. The distribution of respondents by category is shown in Table 1. Of the 1097 respondents (32\% response rate), nearly half $(45 \%)$ attended one or more of the VFLEP workshops. Additional demographic variables are shown in Table 2. Differences in demographics between the categories were relatively minor. Forest
Table 1. Distribution of respondents by educational category ( $n=1$ 097)

\begin{tabular}{lcc}
\hline Category & No. of Respondents & \% \\
\hline VFLEP & 489 & 45 \\
Other & 287 & 26 \\
None & 321 & 29 \\
\hline
\end{tabular}

Table 2. Demographic variables by education category

\begin{tabular}{|c|c|c|c|}
\hline \multirow[b]{2}{*}{ Demographic Variable } & \multicolumn{3}{|c|}{ Education Category } \\
\hline & VFLEP & Other & None \\
\hline Age (yrs.) & 62 & 60 & 65 \\
\hline Level of Education ${ }^{\mathrm{a}}$ & 4.4 & 4.7 & 3.6 \\
\hline$\%$ income from forest & 2.6 & 4.3 & 2.4 \\
\hline Household income $\mathrm{b}^{\mathrm{b}}$ & 3.1 & 3.2 & 2.8 \\
\hline Size of forest (ha) & 86 & 53 & 53 \\
\hline Distance from home to forest $(\mathrm{km})$ & 43 & 19 & 49 \\
\hline Self-rated adoption ${ }^{\mathrm{c}}$ & 3.2 & 3.3 & 2.6 \\
\hline
\end{tabular}

aLevel of education: Scaled from 1 to 6 , where 1 is $<12$ th grade and 6 is graduate degree; 4 = associate or technical degree.

${ }^{b}$ Household income: Scaled from 1 to 5 , where 1 is $<\$ 25000$ and 6 is $\$ 200000$ or more; 3 is $\$ 50000$ to $\$ 100000$.

'Self-rated adoption: Scaled from 1 to 5 , where 1 is an innovator and 5 is a laggard using the scale of Rogers (2003). 2 equates to an early adopter and 3 to a mid-range adopter.

owners who attended educational programs tended to be a little younger and more affluent than those who did not attend any educational programs. Also, VFLEP attendees owned larger forests, 86 ha compared to 53 ha for the other two categories. Respondents were asked to self-rate on an adoption scale of 1 to 5 , where 1 is equivalent to an innovator and 5 a laggard, using the scale of Rogers (2003). Forest owners who did not attend any educational programs averaged 2.6 (between early adopter and mid-range adopter), while forest owners in the other two categories averaged 3.2 (VFLEP) and 3.3 (Other), equivalent to a mid-range to late adopter.

Additional details related to a demographic analysis of the three categories can be found in Rasamoelina et al. (2009).

\section{Adoption of Sustainable Forest Management Practices}

Sustainable forest management practices are those that lead to a resilient and healthy forest that is capable of providing social, environmental, and economic benefits into the future, and are implemented such that forest owners provide their "fair share" of values to society without unfairly exploiting or depriving themselves of values to the detriment or benefit of people in another place or time (Oliver 2003). In our study we categorized sustainable forest management practices as follows: (a) woodland management practices; (b) wildlife management practices; (c) harvesting management practices; (d) development and use of a written forest management plan; (e) use of professional technical assistance; (f) use of financial assistance programs; and, $(\mathrm{g})$ use of conservation easement programs. Woodland management practices included silvicultural techniques such as thinning, pruning, prescribed 
Table 3. Adoption rates (percent) for sustainable forest management (SFM) practices by forest owners in three educational categories

\begin{tabular}{lccc}
\hline & \multicolumn{3}{c}{ Adoption Rate (\%) } \\
\cline { 2 - 4 } SFM Practices & VFLEP & Other & None \\
\hline Woodland management & $94 \mathrm{a}^{\mathrm{a}}$ & $83 \mathrm{~b}$ & $75 \mathrm{~b}$ \\
Wildlife management & $82 \mathrm{a}$ & $74 \mathrm{a}$ & $74 \mathrm{a}$ \\
Harvesting best management & $65 \mathrm{a}$ & $89 \mathrm{~b}$ & $66 \mathrm{a}$ \\
Management plan & $41 \mathrm{a}$ & $22 \mathrm{~b}$ & $12 \mathrm{c}$ \\
Technical assistance & $73 \mathrm{a}$ & $44 \mathrm{~b}$ & $35 \mathrm{~b}$ \\
Financial assistance & $22 \mathrm{a}$ & $36 \mathrm{~b}$ & $9 \mathrm{c}$ \\
Conservation easements & $6 \mathrm{a}$ & $11 \mathrm{a}$ & $6 \mathrm{a}$ \\
\hline
\end{tabular}

${ }^{a}$ Adoption rates within a row followed by the same letter are not significantly different at the 0.10 level.

burning, controlling invasive weeds, tree planting, and fertilizing, as well as some more standard practices such as maintaining painted boundary lines, roads, gates, and culverts (Table 3). Wildlife management practices included enhancing and protecting habitat, controlling invasive weeds, establishing food plots and nesting boxes, installing water holes or ponds, and protecting special places like springs and vernal pools. Harvesting management practices, for those landowners who had harvested trees, included the use of a written contract with a logging contractor, use of marking for designating the trees to harvest, use of a timber cruise to determine the volume of timber to harvest, and use of a regeneration plan (Table 3). Harvesting best management practices (BMPs) are voluntary in Virginia and are prescribed by the Virginia Department of Forestry. They include the use of water bars or other water control structures on roads and skid trails, maintenance of a minimum streamside management zone, and other practices for operations on wet soils to avoid soil damage and unacceptable levels of runoff and sedimentation.

The adoption rates for the various categories of sustainable forest management practices are presented in Table 3. In four out of the seven categories (woodland management, wildlife management, management plan, technical assistance), the VFLEP attendees adopted at a significantly higher rate than either the Other or None categories. Since these were three key objectives of the educational programs, that is certainly confirmation that the educational programs were on target. Foresters and forest owners alike often cite increased educational opportunities as important to increasing management of their woodlands (Jones et al. 1995, Londo and Monaghan 2002, Downing and Finley 2005). Interestingly, the forest owners in the Other category adopted harvesting management practices at the highest rate, $89 \%$, significantly above the other two categories of $65 \%$ for VFLEP and $66 \%$ for None. We attribute this to the flurry of specific Best Management Practice workshops and field days held by the Virginia Department of Forestry and Virginia Cooperative Extension throughout the 1990s and early 2000s. We suspect that many forest owners attended one or more of these targeted workshops, and not VFLEP, which placed them in the Other category. The two remaining practices, financial assistance and conservation easements, were not specific objectives of the original three workshops, however, these practices were mentioned. Neither of the practices had particularly high adoption rates, though $36 \%$ of forest owners in the Other category adopted financial assistance (Table 3). These lower rates led us to create two new workshops just focusing on these topics, as mentioned above.

The forest owners who attended VFLEP workshops did so between October, 1997 and February, 2004, a seven-year span. With the survey being distributed in the spring of 2007, this allowed for a roughly three- to ten-year time frame following workshop attendance, important because the adoption of practices may take several months to as much as 15 years (Rogers 2003). An important finding of this work is that both the development and use of a forest management plan and the use of professional technical assistance were significantly higher for the group that attended VFLEP workshops. These were key educational objectives, since these two practices are often related to improved forest management (Jones et al. 2001). Indeed, the development and use of a management plan is central to the access of certification systems for sustainable forest management, such as the Forest Stewardship Council, Sustainable Forestry Initiative, and American Tree Farm System (Rickenbach 2002). This may be an indicator that in the future more recent VFLEP participants will also adopt at a higher rate.

\section{Evaluating Individual Workshops}

Looking at the adoption rates for forest owners who attended specific workshops reveals fairly high adoption rates. For example, forest owners who attended a wildlife management workshop adopted wildlife management practices at a rate of $82 \%$. Those who attended a woodland management workshop adopted one or more woodland management practices at a rate of $97 \%$. Those who attended a harvesting and marketing workshop adopted best management practices at a rate of $62 \%$. Attendees at any of the workshops adopted written management plans at a rate of $41 \%$ and used technical assistance at a rate of $76 \%$. These are considerably higher than the national average of $4 \%$ for management plans and $14 \%$ for technical assistance (Butler 2008). Additionally, the reinforcing value of attending multiple workshops is evident in Fig. 1, which shows the increasing adoption rate for both management plans and technical assistance as forest owners attend additional workshops. In both cases, the highest adoption rate occurred when forest owners attended all three workshops.

\section{Summary and Conclusions}

This paper clearly associates the adoption of a variety of sustainable forest management practices to participation in forestry extension programs. There are significant relationships between adoption and participation in educational programs for all of the seven categories studied. Two of the categories can also be considered as preliminary steps to additional activity and adoption in the future: technical assistance and management plan. Forest owners frequently cite technical assistance as a desirable and important step toward managing their forests (West et al. 1988, Kilgore et al. 2007). Rasamoelina et al. (2010) determined that technical assistance, management plan, and economic motivation were the three most significant variables in predicting the probability that a given forest owner would adopt SFM practices. 
(a)

Management

Plan

Adoption

Rate

$\%$

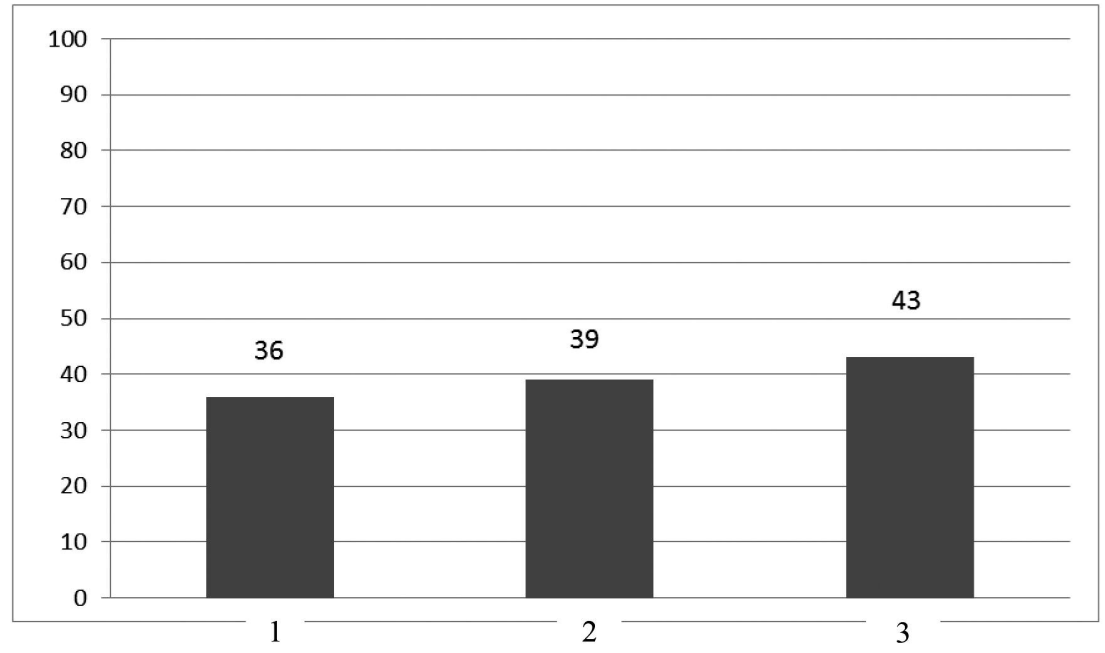

No. of Workshops

(b)

Technical

Assistance

Adoption

Rate

$\%$

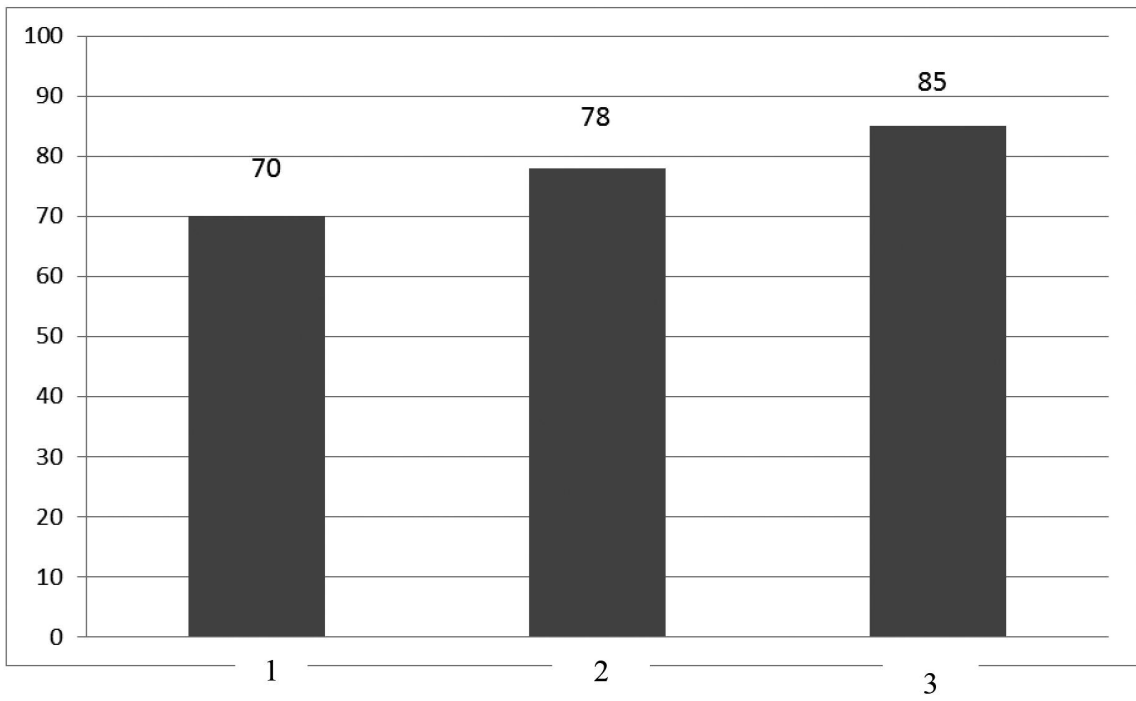

No. of Workshops

Fig. 1. Relationship between number of workshops attended and adoption of forest management plans (a) and technical assistance (b).

An important point to note is that the educational programs discussed in this paper were designed to appeal to forest owners with a variety of interests and motivations. It has long been known that the forest owner community at large consists of groups of individuals with varying motivations for owning land, varying interests in managing their land, and varying objectives (Marty et al. 1988, Rosen and Kaiser 1988, Salmon et al. 2006, Butler et al. 2007). The workshops offered through VFLEP were targeted to owners with general interests in woodland management, interests in wildlife, and economic interests focusing on timber. This no doubt resulted in a broader attendance at these educational programs, and perhaps also a higher rate of adoption.
It is recognized that in the future much of the private forest land in the U.S. will be turning over to a new generation of owners, and in fact, this may already be happening as surveys have shown that parcel sizes are decreasing, a reflection of land subdivisions (Sampson 2000, Butler 2008). This will result in yet a new audience of forest owners that may have a different set of values and motivations than the previous generation, and may also have different learning styles and preferred modes of learning (Kendra and Hull 2005, Mater 2007). Clearly, extension education programs will need to evolve to meet these challenges. 


\section{References}

Birch, T.W., S.S. Hodge and M.T. Thompson. 1998. Characterizing Virginia's private forest owners and their forest lands. USDA For. Serv. Res. Pap. NE-707.

Butler B.J. 2008. Family forest owners of the United States, 2006. USDA For. Serv. Gen. Tech. Rep. NRS-27.

Butler, B.J., M. Tyrell, G. Feinberg, S. VanManen, I. Wiseman and S. Wallinger. 2007. Understanding and reaching family forest owners: Lessons from social marketing research. J. For. 105(7): 348-357 Dillman, D.A. 2000. Mail and internet surveys: The tailored design method. J. Wiley, New York, NY.

Downing, A.K. and J.C. Finley. 2005. Private forest landowners: What they want in an educational program. J. Exten. 43(1), Article rb4, Available from http://www.joe.org/joe/2005february/rb4.shtml [accessed 14 June 2016].

Groves, R.M., D.A. Dilman, J.L. Eltinge and R.J.A. Little (eds). 2002. Survey nonresponse. J. Wiley, New York, NY.

Johnson, J.E. 2000. Forest landowners speak out - The Critical Issues Forum at Smith Mountain Lake. Virginia For. 56(2):18-21.

Johnson, J.E., S.A. Baker and J.D. Starr. 2004. Assessing future directions for forest landowner education in Virginia. Virginia For. 60(1):19-22.

Jones, S.B., A.E. Luloff and J.C. Finley. 1995. Another look at NIPFs - Facing our "myths". J. For. 93(9): 41-44.

Jones, S.B., G. R. Glover, J.C. Finley, M.G. Jacobson and A.S. Reed. 2001. Empowering private forest landowners - Lessons from Pennsylvania, Alabama, and Oregon. J. For. 99(3): 4-7.

Kendra, A. and R.B. Hull. 2005. Motivations and behaviors of new landowners in Virginia. For. Sci. 51(2): 142-154.

Kilgore, M.A., J.L. Greene, M.G. Jacobson, T.J. Straka and S.E. Daniels. 2007. The influence of financial incentive programs in promoting sustainable forestry on the nation's family forests. J. For. 105(4): 184-191.

Londo, A.J. and T.A. Monaghan. 2002. Forest landowner short courses at Mississippi State University. J. Ext. 40(5), Article rb5. Available from: http://222.joe.org/joe/2002october/rb5.php [accessed 14 June 2016].

Lunney, G.H. 1970. Using analysis of variance with a dichotomous dependent variable: An empirical study. J. Educ. Measure. 7(4): 263-269.
Marty, T.D., W.B. Kurtz and J.H. Gramann. 1988. PNIF owner attitudes in the Midwest: A case study in Missouri and Wisconsin. North. J. Appl. For. 5(3): 194-197.

Mater, C. 2007. The new generation of private forest landowners: Brace for change. The Consultant. pp. 12-15.

Oliver, C.D. 2003. Sustainable Forestry - What is it? How do we achieve it? J. For. 101(5): 8-14.

Rasamoelina, M.S., J.E. Johnson and R.B. Hull. 2009. Demographic analysis of family forest owners in relation to educational program participation. In: K. Piatek, B. Spong, S. Harrison and D. McGill (eds.). Proceedings of the International Union of Forest Research Organizations Symposium: Seeing the Forest Beyond the Trees - New Possibilities and Expectations for Products and Services from Small-Scale Forestry, Morgantown, WV, 7-11 June 2009. pp. 202-209. West Virginia University, Morgantown, WV.

Rasamoelina, M.S., J.E. Johnson and R.B. Hull. 2010. Adoption of woodland management practices by private forest owners in Virginia. For. Sci. 56(5): 444-452.

Rickenbach, M.G. 2002. Forest certification of small ownerships. J. For. 100(9): 43-47.

Rogers, E.M. 2003. Diffusion of innovations. Free Press. New York, NY.

Rosen, B.N. and H.F. Kaiser. 1988. Marketing forest management to nonindustrial private forest landowners: A field experiment. North. J. Appl. For. 5(4): 240-244.

Salmon, O., M. Brunson and M. Kuhns. 2006. Benefit-based audience segmentation: A tool for identifying nonindustrial private forest (NIPF) owner education needs. J. For. 104(8): 419-425.

Sampson, R.N. 2000. Forest fragmentation: The future trend for NIPF woodlands? Nat. Woodlands 23(1): 10-11.

USDA Forest Service. 1998. Strategic direction for landowner assistance. USDA For. Serv. Coop. For. FS-621.

West, P.C., J.M. Fly, D.J. Blahna and E.M. Carpenter. 1988. The communication and diffusion of NIPF management strategies. North. J. Appl. For. 5(4): 265-270. 